\title{
A startup vállalkozások terminológiája angol-magyar internetes glosszáriumokban
}

\author{
Polcz Károly \\ E-mail:polcz.karoly@uni-bge.hu
}

\begin{abstract}
Kivonat: A startup vállalkozásokkal kapcsolatos, elsősorban angol nyelvü terminológia jelentős hatást gyakorol más nyelvekre, így a magyar nyelv terminológiájára is. A tanulmány abból a hipotézisböl indul ki, hogy a magyar internetes szakmai oldalakon megjelenő startup glosszáriumokban magas arányban szerepelnek a forrásnyelvből kölcsönzött terminusok. A szótárkészítők vagy átveszik az angol terminusokat, vagy pedig csak a definíciót adják meg célnyelvi ekvivalens nélkül. A kutatásban nyolc internetes angol-magyar startup glosszáriumból összesen 397 terminus szerepel. A forrás- és célnyelvi terminusok kategorizálása adatbázis-kezelő alkalmazás segítségével történt az erre a célra kialakított Terminológiai kontakthatások és fordítási módok taxonómiája alapján (Polcz 2017a, 2017b). Az eredmények azt mutatják, hogy a terminusok közel felében a glosszáriumok vagy nem adnak ekvivalenst, vagy pedig a célnyelvi terminus részben vagy egészben kölcsönzéssel jön létre, utat nyitva ezzel a kódkeverésnek a célnyelvi diskurzusban. A vizsgálat arra is rávilágított, hogy a hiányzó magyar terminusok jelentős része megtalálható egyéb szakmai jellegü internetes oldalakon. A kutatás gyakorlati jelentősége, hogy feltárja a valós lexikai hiányt a magyar nyelvben, rámutatva azokra a pontokra, ahol terminusalkotásra lehet szükség. Ezzel kiindulópontja lehet egy angol-magyar startup terminológiai szótár elkészítésének.
\end{abstract}

Kulcsszavak: startup terminológia, terminusfordítás, szakszótárak, domináns nyelvi hatás, kódkeverés

\section{Bevezető}

Az emberi tudás rohamos fejlődésével és az ehhez kapcsolódó új fogalmak megjelenésével a felhasználók egyre gyakrabban tapasztalják, hogy a professzionális papíralapú vagy online szótárak nem tartalmazzák az új terminusokat. Ez arra sarkalja öket, hogy egyéb terminológiai forrásokból, köztük viszonylag szük szak-

Hivatkozás: Polcz K. 2020. A startup vállalkozások terminológiája angol-magyar internetes glosszáriumokban. Forditástudomány 22. évf. 2. szám. 5-29.

DOI: https://doi.org/10.35924/fordtud.22.2.1. 
mai témakörökre specializálódó online glosszáriumokból is tájékozódjanak. Az online glosszáriumok általában nem professzionális szótárak vagy szószedetek, amelyek szakmai honlapok részeként jelennek meg, többnyire az adott téma szakértőinek szerkesztésében. Így a lexikográfiai és terminológiai képzettséggel láthatóan nem rendelkező szerkesztők nyelvhasználati kérdésekben is véleményvezérekké válhatnak, vagyis az ő megoldásaikat és nyelvhasználatukat a felhasználók feltétel nélkül elfogadhatják és átvehetik.

Az online marketing tárgykörében végzett kutatásomban kimutattam, hogy az internetes glosszáriumokban a terminusok megfeleltetésében jelentős mértékben érződik a domináns nyelv, vagyis az angol terminusok hatása. A forrásnyelvi terminusok közvetlen átvétele óhatatlanul hatást gyakorol a célnyelvi nyelvhasználatra is (Polcz 2017a; 2017b). Feltételezhető, hogy nincs ez másképp a startup cégekhez kapcsolódó magyar terminológia és nyelvhasználat esetében sem.

A tanulmány célja, hogy feltárja a startup glosszáriumok szerkesztői által alkalmazott megfeleltetési és fordítási módokat és az ezek eredményeként keletkezett terminusok jellemzőit angol-magyar nyelvpárban. Az eredményekből következtetések vonhatók le egyrészről a forrásnyelvi terminológia magyar nyelvre gyakorolt hatásáról, másrészről pedig arról, hogy a nyelvhasználók milyen segítséget kaphatnak a vizsgált glosszáriumokban, amikor a startup terminusok célnyelvi megfelelöit keresik.

\section{Domináns nyelvi hatás a magyar szaknyelvhasználatban}

Az elmúlt évek szaknyelvi és terminológiai kutatásaiban egyre inkább előtérbe kerül az angol mint domináns nyelv hatása a magyar terminológiára. A kutatók többek között az orvosi, a pénzügyi, a marketing, a wellness, az informatika és a kémia tárgykörére összpontosították figyelmüket.

Számos kutatásban merül fel az a kérdés, hogy az angol terminusokat hogyan integrálják és használják a magyar diskurzusban. Kis (1993: 564) megfigyelése szerint a számítástechnikai szaknyelv által használt „lexikai állomány több mint 90 százaléka angol eredetü, illetve angol keletkezési mintát követ”. A Számítástechnika című folyóirat egyik számában közölt hirdetések elemzése során beszámolt az idegen szavak jelentős arányáról, valamint rámutatott arra, hogy a nyelvhasználók az angol és a magyar szinonim terminusokat párhuzamosan is használják. A szerző arra a következtetésre jutott, hogy az angol nyelv jelentős hatása természetes folyamat, amelybe nincs értelme beavatkozni.

Szabó (2010) a marketing szaknyelvének vizsgálata kapcsán megállapította, hogy a szerzők azért tartják meg az angol terminusokat, hogy ezzel kiküszöböljék az esetleges félrefordítás és félreértelmezés lehetőségét. Szabó (2010) nagy jelentőséget tulajdonít az adekvát magyar terminusok használatának a szakfordításban, ugyanis álláspontja szerint ez biztosítja a zökkenőmentes szakmai kommunikáci- 
ót, továbbá felhívja a figyelmet a magyar marketingterminológia standardizálására a lehetséges téves értelmezések elkerülése érdekében.

Keresztes (2003) az orvosi terminológiát vizsgálta magyar nyelvü előadásokból, tankönyvekböl, valamint szakmai és félszakmai folyóiratokból összeállított korpusz segítségével. Az eredmények azt mutatták, hogy az előadások és a szakmai folyóiratok nagyszámban tartalmaznak anglicizmusokat. A tankönyvekben az anglicizmusok száma szerzőként változó, és könnyítésképp zárójelben megadják a magyar fordításokat is, míg a félszakmai folyóiratok csak elvétve használnak angol terminusokat. Keresztes (2003) a kutatást orvosokkal készített interjúkkal egészítette ki, hogy feltárja az angol nyelv használatával kapcsolatos attitüdjüket. Az egyik interjúalany egy fiatal szakember volt, aki szerint az angol terminusok pontosabbak és transzparensebbek, éppen ezért úgy vélte, hogy a szakmai kommunikációban a kevert nyelv természetes. Egy középkorú orvos, aki hasonló véleményen volt, hozzátette, hogy az adekvát magyar terminusok hiánya szükségessé teszi az angol terminusok használatát. Egy idősebb professzor azonban nemtetszésének adott hangot a nagyszámú angol terminus beáramlása okán, hangsúlyozva a magyar terminusalkotás fontosságát.

Keresztes (2007) egy másik tanulmányában egyetemi hallgatók fordításaiban mutatta ki az angol nyelv számottevő ortográfiai, nyelvtani és lexikai hatását. A számos tükörfordítás az angol nyelv jelentős szemantikai hatásáról tesz tanúbizonyságot. Következtetése szerint az orvosi szaknyelv különösen hajlamos a nyelvi kölcsönzésre.

Vargáné Kiss (2007) a HVB Bank (jelenleg UniCredit) angol nyelvü vállalati dokumentumait vizsgálva elemezte a nyelvi kölcsönzés különböző formáit és szintjeit. A vizsgálat eredményei azt mutatták, hogy a magyar szövegek nagyszámban tartalmaztak közvetlenül az angol nyelvből átvett terminusokat, valamint görög és latin eredetű nemzetközi vándorszavakat. A szerző a lexikai kölcsönzés két okát emelte ki. Egyrészről a lexikai ür betöltését, vagyis a szerzők kénytelenek átvenni az ekvivalens nélküli angol terminusokat, másrészről pedig a nyelvi divat vagy presztízs hatását, ugyanis az angol kifejezések jobban megragadják a potenciális ügyfél figyelmét. Vargáné Kiss (2016) egy későbbi tanulmányában a 2008-as pénzügyi válsággal kapcsolatos terminológiát vizsgálta a magyar nyelvben. Megállapította, hogy a vizsgált szövegekben gyakran használnak tükörfordítást, de ezzel együtt megadják az angol forrásnyelvi megfelelőt vagy annak rövidítését. További fordítási lehetőségek a hibrid tükörfordítások és a körülírások.

Mátyás (2018) az anglicizmusok arányát vizsgálta eredeti német és németről magyarra fordított szakirodalomban. A német szövegkorpusz 2.600, a magyar 7.160 szót tartalmazott. Az eredmények azt mutatták, hogy a német nyelvű szakirodalomban 14, míg a magyarra fordított szakirodalomban 7 százalékban jelennek meg az anglicizmusok. Mátyás (2018: 424) megállapítása szerint „,az angol kifejezések transzferként hatottak, segítették a szövegértelmezést és a szakemberek közötti kommunikációt". 
Fóris és Bérces (2006: 410) a wellness szaknyelvében mutatott ki hasonló jelenséget, nevezetesen azt, hogy a szakterület „,magyar terminológiájának kialakítása idegen nyelvi átvételekkel [elsősorban az angol nyelvböl] és különböző magyar szakterületek terminusainak átvételével történt”. Álláspontjuk szerint a wellness terminológiájának problematikáját nem a kölcsönszavak jelentik, hanem az egyértelmű definíciók hiánya, amely kevésbé átlátható terminusokhoz és helytelen használathoz vezethet. Az új fogalmak és terminusok nem illeszkednek koherens rendszerbe, ami terminológiai zavart idézhet elö.

Murányiné (2010) az angol mozaikszavak hatását vizsgálta az analitikai kémia területén született $\mathrm{PhD}$-disszertációkban, pontosabban azt, hogy ezek hogyan épülnek be a magyar tudományos diskurzusba. A magyarítás két alapvető formáját azonosította. Az egyik, amikor a magyar mozaikszó betủállománya megegyezik az angoléval, a másik esetben azonban a betüállomány eltérö. Az utóbbi esetben két további lehetőség jöhet számításba. A gyakoribb, hogy az angol mozaikszót módosítás nélkül átveszik, a teljes terminust pedig magyarra fordítják. Ritkább esetben pedig kialakul az ekvivalens mozaikszó. Az egynél több lexémából álló terminusok esetében nagyszámú tükörfordítást, illetve részleges magyarítást is talált. Ez utóbbi azt jelenti, hogy az alakulat egyik eleme tükörfordítással szerepel a szövegben, míg a másik elem esetében megtartják az angol terminust. Murányiné (2010: 186) álláspontja szerint az angol eredetű mozaikszavak használata több előnnyel, mint hátránnyal jár: ,jól magyaríthatók (nincsenek fordítási nehézségek), könnyen toldalékolhatók, jól alkalmazhatók összetételi elötagként; és nem utolsósorban megkönnyítik a nemzetközi kommunikációt (írásban különösen)". A hátrányok között említi a több homonímiát, egyszerre kell ismerni a fogalmat jelölő angol és magyar alakot, továbbá helyesírási és kiejtési problémák merülhetnek fel.

Az online marketing tárgykörében végzett korábbi kutatásaim keretében két nyomtatott és nyolc online glosszáriumban összesen 906 angol terminus magyar nyelvü megfeleltetését vizsgáltam. Az eredmények azt mutatták, hogy a teljes mintában a szótárak szerkesztői 46,2 százalékban alkalmazták a direkt kölcsönzést vagy annak valamely változatát. Ez abban mutatkozott meg, hogy vagy teljes kölcsönzéssel átvették az angol terminusokat, vagy pedig csak a definíciót adták meg célnyelvi ekvivalens nélkül. A célnyelvi elemekből építkező terminusok aránya, mint például a tükörfordítás és az értelemközpontú fordítás 53,97 százalékban volt jelen a mintában. Következésképpen megállapítható, hogy a kölcsönzés viszonylag magas aránya kódkeveréshez, és ezzel idegenszerüséghez vezethet a célnyelvi nyelvhasználatban (Polcz 2017a; 2017b).

A fentiekben bemutatott kutatások értéke abban rejlik, hogy jól felhasználhatók a szaknyelvoktatásban és a szakfordításban, mert feltárják az irányvonalakat az angol nyelvből átvett terminusok használatában. Másfelől azonban, mivel Polcz (2017a; 2017b) és Mátyás (2018) kivételével nem számszerüsítik az eredményeiket, nem is szolgálnak pontos információval arról, hogy az angol terminusok milyen mértékben érintik a magyar nyelvhasználatot. E meglehetősen bonyolult kérdés megválaszolásának első lépése az lehet, hogy megvizsgáljuk az adott tárgykörben 
rendelkezésre álló terminológiai források által javasolt megfeleltetési és fordítási módokat. Ezekből releváns következtetések vonhatók le a magyar nyelvhasználatra vonatkozólag. Jelen tanulmány egyik célja, hogy számszerüen feltárja az angolmagyar startup glosszáriumokban az angol kölcsönszavak, azaz a direkt és részleges kölcsönzés arányát. Az eredmények rávilágíthatnak a szakmai kommunikációban tapasztalt kódkeverés lehetséges okaira.

\section{Hipotézis és kutatási kérdések}

A tanulmány abból a hipotézisből indul ki, hogy a magyar szakmai internetes oldalakon megjelenő startup glosszáriumokban viszonylag magas, közel 50 százalékban szerepelnek a forrásnyelvből átemelt terminusok. Ez azt jelenti, hogy a szótárkészítők vagy teljes kölcsönzéssel átveszik az angol terminusokat, vagy pedig csak a definíciót adják meg célnyelvi ekvivalens nélkül. Mindkét esetben a nyelvhasználó terminushiánnyal szembesül, ami teret adhat a szakmai szövegekben tapasztalható kódkeverésnek (1. 5. pont). A hipotézist az online marketing témakörében végzett hasonló kutatásaimra alapozom (Polcz 2017a; 2017b; 1. 2. pont). A hipotézis mellett a következő kutatási kérdésekre keresem a választ:

(1) Hogyan történik a forrásnyelvi terminusok fordítása/megfeleltetése a vizsgált glosszáriumokban?

(2) Hogyan jellemezhetők az alkalmazott fordítási módok eredményeként keletkezett célnyelvi terminusok?

(3) A célnyelvi terminushiány csak a vizsgált glosszáriumokra vagy a célnyelv egészére jellemző?

\section{A startup terminológia forrásai}

A modern értelemben vett startup világ kialakulása a 90 -es években vette kezdetét az USA-ban található Szilícium-völgyben. A 2000-es évek elején alakultak meg az első inkubátor és akcelerátor programokat kínáló cégek, mint például az Y Combinator és a Techstars. Fö profiljuk a startup vállalkozások segítése és mentorálása, hogy rövid időn belül minél vonzóbbá tegyék őket a kockázati tőketársaságok és befektetési alapok számára. Ők fejlesztették ki az ehhez szükséges módszertani tudást is. A Szilícium-völgyben jött létre elsőként az ún. startup ökoszisztéma, amely magában foglalja a startup világ jellemző tényezőit és szervezeteit, mint például ötletek, innovációk, mentorok, tanácsadók, üzleti angyalok, startup cégek, befektetők, egyetemek stb. (Rao 2013). Ezek alapjaiban határozzák meg a startup világ müködését és nyelvhasználatát. A startup ökoszisztéma hamarosan Magyarországon is müködésbe lendült. 2005-ben kezdte meg tevékenységét a Kitchen Budapest, amely korai fázisú startup cégek indulását segíti. Az első startup 
versenyt 2008-ban szervezték Startup Underground elnevezéssel (Katona 2018). Azóta számos hasonló közösségi eseményre, startup konferenciára került sor, inkubációs és akcelerátor programok is indultak, mint például a Traction Tribe és a Climate-KIC kezdeményezései. A sikeres magyar startupok sem várattak magukra sokáig. Talán köztük is a legismertebbek a Prezi, a Ustream és a Tresorit.

A startup világ szereplői elsőként angol nyelven alakították ki sajátos nyelvhasználatukat és terminológiájukat. A kialakulóban lévő új terminológia azonban nem mindig volt értelmezhető a kezdő vállalkozók számára, ezért a szakemberek egynyelvű glosszáriumokat szerkesztettek, amelyek angol nyelvü tanácsadó oldalak és blogok részeként jelentek meg az interneten. Magyar nyelvi környezetben is több startup tanácsadó internetes oldal és blog indult, amelyekhez angol-magyar terminológiát bemutató glosszáriumok kapcsolódnak. Az angol nyelvü oldalakhoz hasonlóan a szótárak fó célja, hogy a kezdő vállalkozókat megismertessék a startup világ jellemző fogalmaival és terminusaival.

A glosszáriumok elemzése azt mutatja, hogy a startup vállalkozásokhoz köthető terminológia több forrásból is táplálkozik. A terminusok nagyobb hányada a gazdasági terminológia különbözö, szükebb területeihez köthető, míg kisebb részük feltehetően a jogi, a katonai és az informatikai szaknyelven keresztül transzdiszciplináris kölcsönzés (1. ISO 704:2009) útján került be a startupok nyelvhasználatába. A következő nyelvi példák és szócikkek írásmódja a vizsgált források helyesírását tükrözi.

A gazdasági területek terminusait a startup vállalkozások általában jelentésmódosulás nélkül használják, vagyis ugyanarra a fogalomra utalnak velük. Ilyen például a marketing szaknyelvéből a branding (márkaépítés), az online marketingböl a search engine optimization (keresömotor-optimalizálás), a pénzügyböl a preferred stock (elsöbbségi részvény), vagy a menedzsmentböl a board of directors (igazgatótanács) terminusok.

A nem gazdasági területről származó terminusok esetében két jelenség figyelhető meg. Az első esetben a terminust jelentésmódosulás nélkül használják. Ilyen például az SaaS (software as a service - szoftver mint szolgáltatás) betüszó, amely az informatika szaknyelvéhez köthető. Olyan felhőalapú disztribúciós modellt jelent, amelyben a szoftvert az interneten keresztül teszik elérhetővé (Violino 2019). A másik esetben jelentésmódosulás jön létre, vagyis a startupok kontextusában a terminus eltérö fogalomra utal. A stealth mode terminusban a stealth elem etimológiailag a lopás szóra vezethető vissza (Online Etymology Dictionary). A katonai szaknyelvben olyan technológiára utal, amely láthatatlan a radarok számára (Encyclopedia Britannica), míg a startupok nyelvhasználatában egy startup ötlet eltitkolását jelenti a versenytársak elől (startupdate.com). Különösen érdekes a bootstrapping kifejezés, amely a lift yourself up by the bootstraps (saját erejéböl boldogul) idiómára vezethető vissza (Hendrickson 2004: 437). A terminus általánosságban egy önálló, külső segítség nélküli folyamatra utal. Használják az informatikában, a statisztikában és az üzleti életben is. A startupok nyelvhasználatában 
egy startup cég életének első fázisára vonatkozik, mielőtt a külső tőkebevonás megtörténik (startupdate.com).

A startup terminusok egy másik része az általános nyelvből terminologizációval került be a startup ökoszisztéma nyelvhasználatba. Ilyen például az accelerator, amely többek között gázpedált jelent a köznyelvben, míg a startupok tárgykörében a „startup vállalkozások támogatására létrejött magánvállalkozás[ra]” utal (startupdate.com). A hustler szó, amely eredetileg rámenős, ügyeskedő embert jelent egyéb pejoratív jelentések mellett (Országh és Magay 1998: 740), a startupok kontextusában az ügyvitellel és az üzletszerzéssel foglalkozó személyre utal (startupdate.com). Láthatóan a szaknyelvi terminusok a köznyelvi szavak szemantikájából is táplálkoznak.

\section{Startup terminológia és nyelvhasználat}

A magyar nyelvhasználatban két ellentétes felfogás mutatkozik meg. Az egyik kimondottan támogatja az angol terminusok használatát a szakmai kommunikációban. Kádas Péter orvos-közgazdász és startup szakértő, a startupdate.com internetes oldal szerkesztője a következö álláspontot képviseli:

„Továbbra sem gondolom, hogy egy olyan eleve globális iparágban, mint a startup világ, le kellene fordítanunk ezeket a kifejezéseket magyarra - [...], senki nem hal bele, ha megtanulja ezt a néhány szót, [...] mindenhol a világon egy nyelvet fogtok beszélni a befektetökkel” (http://startupdate.hu/startup-szotar).

Általában ez a nyelvfelfogás tükröződik a startup cégekkel foglalkozó honlapok szövegeiben is. A következő szövegrészlet jól illusztrálja a hasonló honlapokra jellemző nyelvhasználatot:

„Vesting nélkül az utcára se menj ki. Double trigger vesting 4 évre, 1 év clifffel. Accelerated vesting-re köss ki külön szabályokat. Magyar Kft-nél reverse vesting-ben gondolkodj" (http://startupdate.hu/nagy-startup-puska).

Hasonló szövegeket olvasva, az angol startup terminológiát nem ismerő befogadó szövegértési nehézségekkel szembesülhet, ami a kódkeverésre vezethető vissza. Ez az a jelenség, amikor a nyelvhasználó két különbözö nyelv elemeit használja egy adott szövegben (Wardhaugh 2010). Egyetérthetünk Drascau (2001) megállapításával, mely szerint a domináns nyelvi környezetben keletkezett terminusok hatással vannak a kevésbé ismert nyelvek terminológiájára. A fenti rövid szövegrészben öt angol terminus is szerepel: vesting, double trigger vesting, cliff, accelerated vesting és reverse vesting. Bár az angol terminusok használata bizonyos esetekben megkönnyítheti a szakmai kommunikációt, felmerül a kérdés, hogy a 
honlap célközönségének, azaz többségükben kezdő startup vállalkozóknak menynyi erőfeszítést kell tenniük, hogy megértsék a közlés tartalmát.

A másik törekvés az angol terminusok magyarítása. Ennek egyik kiemelkedő támogatója a Magyar Bankszövetség, amely pályázatot hirdetett, hogy az angol nyelven használt pénzügyi-gazdasági szakszavakra minél kifejezőbb megfelelöt találjanak. A pályázat nyertes terminusai a következők lettek: innovállalat (startup), pénzpont (ATM), feltöltökártya (prepaid kártya), rendszeres beszedés (csoportos beszedési megbízás) (Szalai 2017). Kérdés, hogy az új terminusok át tudjáke venni az eddig használtak szerepét a köz- és szaknyelvi kommunikációban.

\section{Az online glosszáriumok makro- és mikrostruktúrája}

Mivel a többségükben szakmai oldalakon megjelent startup glosszáriumok nem tekinthetők professzionális terminológiai vagy szaknyelvi szótáraknak, nem várható el az a szerkesztői minőség sem, amelyet a professzionálisan szerkesztett szótárak esetében megszoktunk. Ennek ellenére a nem professzionális szaknyelvi glosszáriumok az internetes korszak releváns nyelvi jelenségei, és mint ilyenek vizsgálhatók a leíró nyelvészet, a lexikográfia, a terminológia és a fordítástudomány paradigmájában. Vizsgálatuk két okból is indokolt. Egyrészről a javasolt célnyelvi terminusokkal vagy azok hiányával hatást gyakorolnak a célnyelvi nyelvhasználatra, másrészről pedig valós igényt elégítenek ki, ugyanis a felhasználó hiába keresné a tárgykör speciális terminusainak többségét a professzionális gazdasági és/vagy üzleti szótárakban.

Bergenholtz és Agerbo (2017) három lényeges lexikográfiai információs igényt emel ki. Ezek a kognitív, a kommunikatív és az operatív szükségletek. Jelen vizsgálat arra világított rá, hogy a glosszáriumok elsősorban a felhasználók kognitív és kommunikatív szükségleteit igyekeznek kielégíteni. A kognitív szükséglet tekintetében alapvető ismeretekkel ruházzák fel a kezdő startup vállalkozókat, míg a kommunikatív szükségletet a szövegértés, a szövegalkotás és a fordítás támogatásával elégítik ki.

A professzionális szótárakhoz hasonlóan, az online glosszáriumok tartalma a makro- és mikrostruktúrájuk alapján írható le. A makrostruktúra a szótári címszavak típusára és elrendezésére, valamint a szótárban található támogató anyagokra utal, míg a mikrostruktúrán a szótári bejegyzések felépítését és tartalmát értjük (Atkins és Rundell 2008). Az elemzés Atkins és Rundell (2008), valamint Fuertes-Olivera és Tarp (2014) által megadott szempontok alapján történt.

A makrostruktúra tekintetében megfigyelhető, hogy a címszavak elrendezése a glosszáriumok közül hatban az ábécé sorrendjét követi, míg kettő a tematikus elrendezést választotta. Ez utóbbiak a terminusokat négy-négy témakörbe csoportosították: üzlet, pénzügy és befektetés, marketing, titulusok (mszk-bme.hu), valamint pénzügyi, üzleti, marketing, programozói és fejlesztési kifejezések (vespuccipartners.com). Az egyes témakörökön belül a terminusok ábécé sorrendben sze- 
repelnek. A címszavak között megtalálhatók a startup ökoszisztéma nyelvezetére jellemző speciális terminusok (pl. termsheet, deck, double-trigger vesting stb.), valamint az egyéb, főleg gazdasági területek terminusai (1. 4. pont).

Az ISO kategorizálása szerint a terminológiai megnevezések (designations) terminusokra (terms), egyedi elnevezésekre (apellations) és szimbólumokra (symbols) bonthatók (ISO 704:2009). Az egyszerü, vagyis az egy tagból álló terminusokon kívül a szótárak tartalmaznak többszavas kötöjellel írt (pl. one-pager - vezetöi összefoglaló) vagy kötöjel nélküli alakulatokat (convertible debt-részesedésre váltható hitel), idiomatikus kifejezéseket (friends, family and fools - elsö körös befektetők), szóösszevonásokat (custdev [customer + development] - üzletfejlesztés), betüszavakat (MVP: minimum viable product-prototípus) és csonkított terminusokat (cap table - capitalization table). Az egyedi elnevezésekre is található néhány példa (pl. JEREMIE, Google Adwords, Google Analytics). Szimbólumokat a glosszáriumok nem tartalmaznak.

A makrostruktúra másik lényeges eleme a támogató anyagok. Ezek alatt a szótárak bevezetőjét, a célcsoport meghatározását, a használati útmutatóját, a jelés szimbólumrendszerét, valamint a különböző nyelvi és konverziós segédtáblázatokat értjük. A glosszáriumok közül hatban található rövid, néhány soros bevezetö, amelyben a szerkesztő ismerteti a szótár célját (startupdate.hu, startup-marketingakademia.hu, mszk-bme.hu, ahabrain.store, speaknyelviskola.hu, start2act.eu). A másik két glosszárium támogató anyagot nem tartalmaz (mvmedison.hu, vespuccipartners.com).

A szótárak mikrostruktúrája is egyszerü felépítést mutat. A szócikk általában a forrásnyelvi terminust, a célnyelvi terminust és a célnyelvi definíciót foglalja magában a következőképpen: „Angel investor Üzleti angyal - legtöbbször korábbi sikeres vállalkozó -, aki saját magántőkéjét fekteti egy-egy induló cégbe" (startupdate.com). Viszonylag gyakran elöfordul, hogy a célnyelvi terminus hiányzik a szócikkből: „Accelerator Startup vállalkozások támogatására létrejött magánvállalkozás [...]" (startupdate.com). A nyelvhasználók a hiányzó célnyelvi terminust bizonyos esetekben a definícióból nyerhetik ki: „Preferred stock Bizonyos elöjogokat (általában különböző vétókat) biztosító elsőbbségi részvényosztály, melyet a befektetők kapnak, szemben egy startup alapítói által birtokolt Common Stockkal" (startupdate.com). A célnyelvi terminus (elsőbbségi részvény) a definícióban explicit módon szerepel. Ritkán bár, de előfordul, hogy a szócikk csak a magyarított terminust és annak definícióját tartalmazza, a forrásnyelvi terminust a definícióból kell kikövetkeztetni: „Akcelerátor: az akcelerátorok magánvállalkozások, amik a pre-seed vagy seed fázisban karolják fel a vállalkozásokat [...]" (ahabrain. store). Egyes szócikkekben csak a definíció tartalmazza a forrásnyelvi terminust: „Monetizáció Az angol monetization szó magyarítása, pénzkeresetet, pénzzé tételt jelent” (startupdate.com). Bizonyos szócikkekből hiányzik a definíció: „Fund: befektetési alap" (ahabrain.store). Az 5. pontban tárgyalt kódkeverés a definíciókban is gyakran megjelenik: „A term sheet-ek egy lényeges gazdasági jellegü pontja, ami a befektetőket védi egy későbbi, az általuk meghatározottnál kisebb cégérté- 
keléstöl. Normális formája a broad-based average antidilution, előnytelen formája a full-ratchet antidilution" (startupdate.com). A terminusokra vonatkozó egyéb információkat, úgymint kiejtés, szófaj, ragozás, használat, példamondat, etimológia stb. a glosszáriumok nem tartalmaznak.

\section{EIméleti háttér}

\subsection{Pragmatikai aspektusok}

Morris (1946) értelmezésében a pragmatika tárgya a jelek és azok értelmezői közötti viszony tanulmányozása. Ebből adódóan egy adott tárgykör terminusainak transzparenciája csak úgy vizsgálható, ha figyelembe vesszük a kommunikációban részt vevő feleket, mivel a terminusok értelmezését jelentősen meghatározza a nyelvhasználó háttérismerete. A glosszáriumok szerkesztői a terminusok definiálásával egyrészről a szakszövegek megértésében nyújtanak segítséget, a célnyelvi ekvivalensek megadásával vagy ezek esetleges hiányával pedig a célnyelvi nyelvhasználattal kapcsolatban adnak iránymutatást. A szerkesztők gyakran a forrásnyelvi terminusokat részesítik előnyben, más esetekben pedig célnyelvi elemekből építkező terminusokat javasolnak. Míg a szakemberek természetes könnyedséggel használják az angol terminusokat a magyar nyelvü diskurzusban, addig a forrásnyelvből átemelt terminusok idegenszerüséget okozhatnak a szakember és a laikus közötti kommunikációban, ugyanis ezeket a laikus nyelvhasználó kódváltásként érzékeli. Minél többször kerül sor kódváltásra, annál idegenszerübb szöveggel szembesül.

A tanulmány középpontjában egy átlagos müveltséggel rendelkező modell személy áll, akit laikus nyelvhasználónak nevezek. A célnyelvi ekvivalensek transzparenciáját az ő szempontjából igyekszem megvilágítani. Azt vizsgálom, hogy a glosszáriumokban szereplő ekvivalensek hogyan járulnak hozzá a szakember és a laikus közötti kommunikáció megkönnyítéséhez.

Az ISO 704:2009 szabvány szerint azt a terminust nevezzük transzparensnek, amely definíció nélkül is - legalábbis részben - értelmezhetö. A célnyelvi startup terminusok vizsgálata arra világított rá, hogy a laikus nyelvhasználó szempontjából a transzparencia három szintjét érdemes megkülönböztetni: a terminusok lehetnek interferenciálisak, intranszparensek és nyelvileg transzparensek.

Interferenciális terminusnak azokat az ekvivalens nélküli vagy célnyelvbe átemelt forrásnyelvi alakulatokat nevezem, melyek használatát a laikus nyelvhasználó kódváltásként érzékeli. A célnyelvi diskurzusban sem a nyelvi, sem pedig a fogalmi szint nem értelmezhető (pl. bootcamp, bridge loan, cap table stb.).

Az intranszparens terminusok szük szakmai körben használt idegen vagy nemzetközi szavak. A célnyelvbe általában nyelvi honosítással (naturalization) kerülnek, amely Newmark (1988) értelmezésében azt jelenti, hogy a forrásnyelvi elemet a célnyelv fonológiai és morfológiai rendszeréhez igazítják, mint például a monetizáció (monetisation) terminus esetében. Fontos megjegyezni, hogy ez nem 
azonos a terminusok fogalmi szintű megfeleltetése során alkalmazható honosító (domesticating) stratégiával (1. Fischer 2012). A nyelvi honosítás miatt az intranszparens terminusok használatát a nyelvhasználó nem érzékeli egyértelmủ kódváltásként. Mivel azonban a szóalak kevéssé ismert, a fogalmi tartalom pedig ismeretlen az adott tárgykörben, használatuk szövegértési nehézséget jelenthet. Ezek tehát nyelvi és fogalmi szinten is homályos terminusok, bár bizonyos mértékben már beépültek a célnyelvbe.

A nyelvileg transzparens terminusok azok az alakulatok, amelyek esetében a szóalak széles körben ismert és használt, a teljes fogalmi tartalom adott tárgykörben azonban nem feltétlenül (pl. közösségi finanszírozás, vásárlói élmény, felhígulás).

A transzparencia következő szintje a fent említett, ISO 704: 2009 szabvány által definiált fogalmi transzparencia. Bár a szakszerü terminusalkotás a fogalom bizonyos aspektusait transzparenssé teheti definíció nélkül is, álláspontom szerint a részleges vagy teljes fogalmi transzparenciát nehéz lenne egyértelmüen behatárolni, ezért a fogalmilag transzparens terminusok külön kategóriába sorolására a tanulmány nem vállalkozik.

\subsection{Terminológiai kontakthatások és fordítási módok}

A startup vállalkozásokkal kapcsolatos terminusok túlnyomó részben tudástranszferrel, így másodlagos terminusalkotással kerültek a magyar nyelvbe. Ez azt jelenti, hogy egy másik nyelvben, jelen esetben az angol nyelvben már létezett terminus az adott fogalom nyelvi megjelenítésére. Sager (1998) szerint a másodlagos interlingvális terminusalkotásnak többféle módja van, mint például a kölcsönzés, a tükörfordítás, a parafrazálás, a parallel fordítás, az adaptáció és az új terminusalkotás. A másodlagos terminusalkotás során kontakthatás jön létre a forrás- és a célnyelvi terminus között. A kontakthatásokhoz különböző fordítási módok köthetök.

Az 1. táblázat a kontaktnyelvészetből (Haugen 1950; Kontra 1981; Lanstyák 2006) és a fordítástudományból (Newmark 1988; Vinay és Dalbernet 1995) ismert rendszerek alapján egy olyan taxonómiát mutat be, amelynek segítségével kategorizálhatók a vizsgált startup glosszáriumok szerkesztői által alkalmazott másodlagos terminusalkotási módok. A taxonómia az online marketing terminológiájának vizsgálatára létrehozott rendszer továbbfejlesztett változata, amely összesen több mint 1.300 angol-magyar terminus megfeleltetésének elemzésével került kialakításra (Polcz 2017a; Polcz 2017b).

A taxonómia fö szervező elve a nyelvi kontakthatás, a kapcsolódó fordítási módok, valamint az interferenciális hatás. A nyelvi kontakthatás kapcsán a tanulmány azt vizsgálja, hogy a forrásnyelvi terminus hogyan hat a célnyelvi terminusra. Az interferenciális hatás arra utal, hogy a fordítás eredményeként keletkezett célnyelvi terminusok hogyan és milyen mértékben járulnak hozzá az 5. pontban bemutatott kódkeveréshez. A kontakthatások és a fordítási módok feltérképezésével fény derülhet arra, hogy a glosszáriumok mennyiben segítik a nyelvhasználót 
a célnyelvi terminusok megtalálásában, valamint hozzájárulhat ahhoz, hogy jobban megértsük a fentiekben bemutatott kódkeverés okait.

Az 1. táblázat három fö oszlopa tartalmazza a terminológiai kontakthatásokat, az ezekhez kapcsolódó fordítási módokat, valamit azt, hogy ennek eredményeként hogyan alakul a célnyelvi terminus transzparenciája. A forrásnyelvi terminus hatása egy skála mentén jellemezhető, amelynek két végpontja a direkt és a zéró hatás. E két végpont között számos átmenet figyelhető meg, ahogy ez a táblázatban látható.

1. táblázat

Terminológiai kontakthatások és fordítási módok

\begin{tabular}{|c|c|c|c|}
\hline \multicolumn{2}{|c|}{ Kontakthatás } & Fordítási mód & Eredmény \\
\hline \multirow[t]{5}{*}{ direkt hatás } & - & zéró fordítás & interferenciális terminus \\
\hline & \multirow{2}{*}{$\begin{array}{l}\text { direkt } \\
\text { kölcsönzés }\end{array}$} & átemelés & \\
\hline & & nemzetközi szó & $\begin{array}{l}\text { intranszparens/nyelvileg } \\
\text { transzparens terminus }\end{array}$ \\
\hline & \multirow[t]{2}{*}{ hibridizáció } & hibrid átemelés & interferenciális terminus \\
\hline & & hibrid nemzetközi szó & $\begin{array}{l}\text { intranszparens/nyelvileg } \\
\text { transzparens terminus }\end{array}$ \\
\hline \multirow[t]{2}{*}{$\begin{array}{l}\text { indirekt } \\
\text { hatás }\end{array}$} & \multirow[t]{2}{*}{$\begin{array}{l}\text { indirekt } \\
\text { kölcsönzés }\end{array}$} & $\begin{array}{l}\text { helyettesítés } \\
\text { - tükörfordítás, } \\
\text { - jelentéskölcsönzés }\end{array}$ & $\begin{array}{l}\text { nyelvileg transzparens } \\
\text { terminus }\end{array}$ \\
\hline & & $\begin{array}{l}\text { helyettesítés értelmezéssel } \\
\text { - részben értelemközpontú } \\
\text { fordítás }\end{array}$ & \\
\hline zéró hatás & - & értelemközpontú fordítás & \\
\hline
\end{tabular}

Az 1. táblázat alapján a nyelvi kontakthatás három alaptípusát, a direkt, az indirekt és a zéró hatást különböztetjük meg. A kontakthatások további alkategóriákra bonthatók, amelyekhez különböző fordítási módok kapcsolhatók. A direkt hatás, vagyis amikor a forrásnyelvi terminus közvetlenül hat a célnyelvi terminusra, háromféleképpen valósulhat meg. Az első esetben a terminológiai forrás csupán definiálja a fogalmat, de nem ad célnyelvi megfelelőt, vagyis a célnyelvi terminus helye üresen marad. Ekkor azt feltételezhetjük, hogy a nyelvhasználó jó eséllyel az angol terminust fogja használni a célnyelvi diskurzusban. Ezt a megoldást zéró fordításnak nevezzük. Ilyen terminusok például az accelerator, antidilution, bootstrapping, deck stb. (startupdate.com).

A direkt hatás másik megvalósulási formája a direkt kölcsönzés, amely morfémaátvétellel jár, eredménye pedig az idegen szó vagy kölcsönszó (Kontra 1981: 
14). A direkt kölcsönzéshez kapcsolható két fordítási mód, az átemelés és az idegen vagy nemzetközi szó használata jelentéskölcsönzéssel vagy azonos jelentéssel.

Az átemelés arra a jelenségre utal, amikor a szótárszerkesztő a forrásnyelvi terminust változatlan formában teszi át a célnyelvi terminus helyére vagy annak környezetébe. Ez a megoldás a fordítástudományban transzliterációként (Newmark 1988) vagy transzkripcióként (Harvey 2000) ismert. Ilyen terminusok például a growth hacking (jelentős növekedést elérö marketingstratégia [vespuccipartners. com]), a pre-seed (startup életének első szakasza [startupdate.com]) stb. Gyakran előfordul, hogy az átemelt forrásnyelvi terminus jól illeszkedik a magyar nyelv fonológiai és morfológiai rendszerébe, vagyis könnyen kiejthető és jelentősebb módosítás nélkül ragozhatóvá válik, mint például a pivotol (stratégiai irányváltást hajt végre [startupdate.com]), bootstrappel (saját magát finanszírozza [vespuccipartners.com]) terminusok esetében. Az interferenciális hatás kimutatása érdekében ebbe a csoportba soroljuk azokat a szókapcsolatokat is, amelyeknek legalább egyik elemét a szótárkészítő teljes kölcsönzéssel átemelte, a másik eleme pedig idegen vagy nemzetközi szó, mint például a lead generálás (potenciális érdeklödőket szerez [vespuccipartners.com]) terminus. Bár a generálás terminus nyelvileg és fogalmilag széles körben ismert, az alakulat másik tagja a lead interferenciát okozhat. A zéró fordítás és az átemelés eredménye lényegében ugyanaz. A laikus nyelvhasználó interferenciális terminussal szembesül, amit kódváltásként érzékel a diskurzusban.

A másik fordítási mód a nemzetközi szó használata. Az angol terminus direkt hatása ebben az esetben úgy érvényesül, hogy a szótárszerkesztő az angol nyelvbe is gyakran kölcsönzéssel került elem célnyelvi ekvivalensét adja meg. Ilyen például az ecosystem - ökoszisztéma terminuspár. Ez a fordítási mód felfogható egyfajta tükörfordításnak is, hiszen az idegen szó, igaz más tárgykörben, de megtalálható a célnyelvi rendszerben. Mindazonáltal az interferenciális vagy idegen hatás kimutatása érdekében ezeket a terminusokat a kölcsönzések közé sorolom.

A nemzetközi szavak jelentéskölcsönzéssel vagy azonos jelentéssel kerülnek be a tárgykör célnyelvi terminusai közé. A jelentéskölcsönzés arra utal, hogy az egy vagy több idegen szóból álló alakulat legalább egyik eleme a vizsgált tárgykörben új jelentéssel bővül. Ilyen például az akcelerátor terminus, amely eredetileg a latinra vezethető vissza, de az angol nyelvből került a magyarba. Jelentése a müszaki nyelvben gázpedál, a kémiában pedig ,vegyi folyamatokat gyorsító anyag” (Tóthfalusi 2008: 24). A szóalak tehát nem a startupok megjelenésével került be a célnyelvbe, hanem jóval korábban más tárgykörökben. A startupok terminológiájában olyan vállalkozásokra utal, amelyek szakmai vagy anyagi segítséget nyújtanak a korai fázisú cégeknek (vespuccipartners.com). Léteznek olyan nemzetközi szavak, amelyeknél nem figyelhető meg jelentésbővülés, mert ezek fogalmi tartalma minden tárgykörben azonos: workshop, direkt marketing, startup stb.

A nemzetközi szóval történő fordítás esetenként intranszparens célnyelvi terminust eredményezhet, vagyis a szóalak ismerős a laikus nyelvhasználó számára, de mivel csak szűkebb szakmai csoportok használják, idegenszerüséget okozhat a 
diskurzusban (pl. iteráció, validáció, monetizáció stb.). Más esetekben olyan nyelvileg transzparens terminusok kerülnek a célnyelvbe, amelyek más tárgykörökböl már széles körben ismertek (pl. unikornis, inkubátor, evangelista). Ezek fogalmi tartalma ugyan definíció nélkül rejtve marad a laikus nyelvhasználó számára, de használatuk kevésbé teszi idegenszerüvé a diskurzust.

A direkt hatás másik megvalósulási formája a hibridizáció. Ekkor az alakulat egyik eleme kölcsönzéssel, a másik eleme pedig helyettesítéssel kerül a célnyelvbe. A hibridizáció tehát morfémaátvétellel és morfémahelyettesítéssel is jár (Haugen 1950: 210; Kontra 1981: 15), és mint ilyen sajátos átmenetet képez a direkt és az indirekt hatás között. Ezt a jelenséget mégis azért célszerű a direkt hatás kategóriájába sorolni, mert a nyelvi interferencia kimutatásának szempontjából ez a meghatározó. A hibrid fordítás két típusát különböztetjük meg. Az egyik a hibrid átemelés, a másik pedig a nemzetközi szót tartalmazó hibrid alakulattal történő fordítás.

A hibrid átemelés során az egyik elem változtatás nélkül, a másik elem pedig helyettesítéssel kerül a célnyelvbe, mint például a double trigger vesting - gyorsított vesting; hockey stick - hockey stick növekedés terminusok. Ez a fordítási mód interferenciális terminust eredményez, mivel használatát a laikus nyelvhasználó kódváltásként érzékeli.

A hibrid fordítás másik megjelenési formája a nemzetközi szót tartalmazó hibrid alakulat. Ez legalább két elemből álló szókapcsolat, amelynek egyik eleme nemzetközi, a másik eleme pedig célnyelvi szó. Gyakran előfordul, hogy a nemzetközi szó jelentése bővül az adott kontextusban, mint például a piaci penetráció terminus esetében. A latin eredetü penetráció behatolást, benyomulást jelent. A startupok kontextusában arra utal, hogy a startup cég a célpiac bizonyos százalékát milyen gyorsan tudja elérni (vespuccipartners.com). Más terminusok esetében hasonló jelentésbővülés nem figyelhető meg. Ha például megvizsgáljuk az ügyfélkapcsolati menedzsment szoftver terminust, akkor azt tapasztaljuk, hogy a menedzsment és a szoftver terminusok fogalmi tartalma a startupok tárgykörében nem változik. A nemzetközi szót tartalmazó hibrid alakulatok intranszparens és nyelvileg transzparens terminusokat is eredményezhetnek hasonlóan a direkt kölcsönzés kapcsán tárgyalt nemzetközi szavakhoz.

Az 1. táblázat második sora az indirekt hatás megjelenési formáit mutatja be. Ez arra utal, hogy a forrásnyelvi terminus csak közvetetten hat a célnyelvire. Ennek megvalósulása az indirekt kölcsönzés, az ehhez kapcsolható fordítási mód pedig a helyettesítés. Ekkor a szótárkészítő a forrásnyelvi terminus szemantikai, szótári megfelelőjét adja meg. Lanstyák István (2006) a helyettesítés két típusát idézi, nevezetesen a tükörfordítást és a jelentéskölcsönzést. Tükörfordításról, illetve ennek eredményeként létrejövő tükörszóról akkor beszélhetünk, ha a forrásnyelvi terminus legalább két morfémára tagolódik (Balázs 1983), mint például az angel investor - angyal befektetö esetében. A helyettesítés másik típusa a jelentéskölcsönzés, amikor a forrásnyelvi terminus egyetlen morfémából áll (Balázs 1983). Ilyen a dragon - sárkány terminuspár, amely a startup cégek tárgykörében nagy- 
befektetőt (vespuccipartners.com) jelent. A helyettesítés eredményeként a köznyelvi szó terminologizálódik, vagyis olyan szakmai tartalmat jelenít meg, amely elözőleg nem kapcsolódott hozzá. A helyettesítés harmadik lehetséges formája a helyettesítés értelmezéssel, vagyis a részben értelemközpontú fordítás. Ebben az esetben a célnyelvi terminus egyik eleme a forrásnyelvi terminus szemantikai vagy szótári megfelelöje, míg a másik eleme értelmezéssel jön létre. Ilyen terminus például a seed investment - magvetö befektetés vagy a smart money-okostöke.

A helyettesítés eredménye nyelvileg transzparens terminus. Ha a helyettesítés értelmezéssel ötvöződik, az értelmező fordítás rávilágíthat a fogalmi tartalom bizonyos aspektusaira is: a magvetö befektetés a korai szakaszban nyújtott finanszírozásra utal (start2act.eu), az okostöke pedig olyan befektetésre, amikor nemcsak anyagi eszközökkel, de tudással, kapcsolati tőkével és mentorálással is segítik a startup vállalkozást (vespuccipartners.com).

A táblázat harmadik sorában szereplő zéró hatás azt jelenti, hogy a forrásnyelvi terminus nyelvi szinten nem hat a célnyelvire. Az ehhez kapcsolható fordítási mód az értelemközpontú fordítás, vagyis a szótárkészítő olyan célnyelvi megfelelöt ad meg, amely nemcsak nyelvileg teszi transzparenssé a terminust, hanem rávilágít a fogalom lényegi aspektusaira is. Ez megfeleltetéssel és értelmező fordítással történhet. Megfeleltetésről akkor beszélhetünk, ha a fogalom egyéb gazdasági tárgykörben már ismert a célnyelvi kultúrában, a szótárkészítő pedig a definíció alapján ezt a fogalmat megjelenítő terminust keresi meg a célnyelvi rendszerben: due diligence - átvilágitás (vespuccipartners.com). Az értelmező fordítás azt jelenti, hogy a szótárkészítő a definíció alapján értelmezi a fogalmat, majd pedig célnyelvi elemekből építkező terminust alkot: net promoter score - ügyfélelégedettségi méröszám (startup-marketing-akademia.hu; traction - haladás (startupdate.com). Így olyan ekvivalenciák jönnek létre, amelyek előzőleg nem léteztek.

\section{Adatok és a vizsgálat módszere}

A tanulmány leíró jellegéböl adódóan startup terminológián azon terminusok öszszességét értjük, amelyek Startup glosszárium/szótár cím alatt jelentek meg internetes oldalakon. A vizsgálatban nyolc internetes glosszárium szerepel, amelyek összesen 397 terminust tartalmaznak. A glosszáriumok közül hét szakmai honlapokon jelent meg. Az ahabrain.store az Antenna Hungária akcelerátor programja vállalkozók számára, a startupdate.hu Kádas Péter startup szakértő szakmai oldala, az mszk-bme.hu a Budapesti Müszaki és Gazdaságtudományi Egyetem Management Szakkollégiumának honlapja, a vespuccipartners.com a Vespucci Partners kockázati tőkealap-kezelő cég oldala, a startup-marketing-akademia.hu Farkas Zsolt a 7 Digits Growth Marketing Agency ügyvezető igazgatójának honlapja, az mvmedison.hu az MVM (Magyar Villamos Múvek) Csoporthoz tartozó MVM Edison startup képzési programja. A feldolgozott anyagban szerepel a start2act.eu honlapjáról PDF formátumban letölthető Startup mentorálási kézikönyv részeként 
megjelent startup szótár. Az egyetlen nem szakmai oldalon elérhető glosszárium a speak.hu nyelviskola honlapján található. A terminusok számát tekintve a vizsgált szótárak eltéröek. A legnagyobb 174 (vespuccipartners.com), míg a legkisebb mindössze tíz terminust tartalmaz (speak.hu).

A terminusok fordításában megfigyelhető tendenciák feltérképezése Microsoft Access adatbázis-kezelő program segítségével történt. Az angol és a magyar terminusok, valamint a célnyelvi definíciók manuális adatbevitellel kerültek az adatbázisba. Célnyelvi terminushiány esetén az adatmezőbe zéró (z) jelzés került. Ez azt jelenti, hogy a szótárszerkesztő csak a forrásnyelvi terminust szerepelteti a glosszáriumban. Nem tekintettem zéró fordításnak azokat az eseteket, amikor a célnyelvi terminus nem a szokásos helyén szerepel a glosszáriumban, de a szócikk egyéb részében, elsősorban a definícióban megtalálható.

Kiemelt figyelemmel kellett eljárni a célnyelvi szavakból építkező és a más nyelvekböl átvett terminusok megkülönböztetésében. Az idegen nyelvekből átvett szavak között az etimológiai szakirodalom megkülönbözteti a jövevény-, idegen és nemzetközi szavakat. A régebben átvett jövevényszavakat idegen eredetük ellenére nyelvérzékünk szokványos magyar szavakként kezeli, idegen eredetüket már nem érzékeljük. Ezzel szemben azokat a szavakat, amelyeket a laikus nyelvhasználó idegennek érez, az idegen szavak kategóriájába soroljuk. A nemzetközi szavak pedig olyan idegen, többnyire görög vagy latin eredetű szavak, amelyek több nyelvbe hasonló jelentéssel és hangalakkal kerültek be (Falk 2009). Könnyen belátható, hogy a nyelv és a nyelvhasználat dinamikus változása okán ezek a kategóriák állandó mozgásban vannak, ami a pontos besorolást jelentősen megnehezíti. A lexikográfiai vizsgálatban azonban mégis szükség van a besorolást lehetővé tévő objektív kritériumok felállítására.

Az átemelések közé azokat a terminusokat soroltam, amelyeket a szótárkészítő változatlan formában vett át a forrásnyelvből, valamint idegen szavak szótárában még nem szerepelnek. Az idegen szavakból építkező terminusok közé azokat soroltam, amelyek az idegen szavak szótárában megtalálhatók (pl. Tóthfalusi 2008). Ezek vizsgálata arra világított rá, hogy nagyrészük hasonló hanglakban több európai nyelvben megtalálható, ezért a taxonómiában ezek a fordítás nemzetközi szavakkal kategóriában szerepelnek (1. 7.2 pont). A jövevényszavakat a célnyelv saját elemeiként kezeltem.

Az adatbevitel után a kódolási szakasz következett. Az 1. táblázatban ismertetett taxonómia alapján minden terminuspárt a fordítási módot jelölő kóddal láttam el a következők szerint: $\mathrm{z}=$ zéró fordítás; á = átemelés; $\mathrm{n}=$ nemzetközi szó; há $=$ hibrid átemelés; $\mathrm{hn}=$ hibrid nemzetközi szó; $\mathrm{h}=$ helyettesítés; réf $=$ részben értelemközpontú fordítás; é = értelemközpontú fordítás. A fordítási mód mellett jelöltem a fordítás eredményeként keletkezett terminus jellemzőjét: if $=$ interferenciális terminus; it = intranszparens terminus; $n y t=$ nyelvileg transzparens terminus.

A nyelvi adatok kódolásának megbízhatóságát nyelvész kolléga bevonásával biztosítottam. A kódolást egymástól függetlenül végeztük el, majd az eredményeket összehasonlítottuk, az esetleges eltéréseket pedig tisztáztuk. A Cohen's Kappa 
értékek a három vizsgált változó esetében a következőképpen alakultak: fordítási módok $\mathrm{k}=0,899$; nyelvi transzparencia $\mathrm{k}=0,90$; nyelvi transzparencia széles spektrumú vizsgálata $\mathrm{k}=0,807$. A kódolók közötti megbízhatóságra vonatkozó értékek erős vagy majdnem tökéletes egyezést mutatnak.

Az adatbázis-kezelő programban a kódok alapján végzett lekérdezésekkel feltárhatók a szótárszerkesztők által alkalmazott leggyakoribb fordítási módok, valamit a fordítás eredményeként keletkezett terminusok jellemzői. Ennek ismeretében következtetések vonathatók le arról, hogy a vizsgált glosszáriumok milyen nyelvi segítséget nyújtanak a célnyelvi terminusok tekintetében.

A harmadik kutatási kérdés arra vonatkozik, hogy a terminushiány csak a vizsgált glosszáriumokra, vagy pedig a célnyelv egészére jellemző. Ennek érdekében széles spektrumú vizsgálatot végeztem, amelyet keresőmotor segítségével a teljes internetre kiterjesztettem, rákeresve azokra a terminusokra, amelyek a gloszszáriumok alapján nem rendelkeztek nyelvileg transzparens megfelelökkel. Az interneten felhalmozott nyelvi anyag nagysága miatt természetesen csak a legrelevánsabb találatok vizsgálatára volt lehetőség. A széles spektrumú vizsgálat eredményeit összevetettem a glosszáriumokban feltárt fordítási módokkal.

\section{Eredmények}

Az 1. diagram azt szemlélteti, hogy az 1. táblázatban bemutatott fordítási módok milyen arányban szerepelnek a teljes mintában. Mivel a glosszáriumokban bizonyos terminusok ismétlődnek, a százalékos arányok terminusismétlődésekkel értendők. Az ismétlődéseket két okból is célszerü figyelembe venni. Egyrészről azért, mert előfordul, hogy a glosszáriumok ugyanazon terminus esetében másmás fordítási módot alkalmaznak. Másrészről pedig azért, mert a diagram adatai arra is rávilágítanak, ha a nyelvhasználó csak az egyik glosszáriumban keres, vagyis nem használja ki mind a nyolc glosszárium által nyújtott lehetőséget, akkor milyen eséllyel fordul elö, hogy nem talál célnyelvi terminust (zéró fordítás), vagy csak a forrásnyelvből átemelt terminust, esetleg részben átemelt hibrid alakulatot talál. Ezek a fordítási módok eredményezik az interferenciális vagy intranszparens célnyelvi terminusok döntő hányadát. A hasonló alakulatok nehezebben illeszkednek a célnyelvi diskurzusba, és zavart okozhatnak elsősorban a szakember és a laikus közötti kommunikációban. 


\section{1. diagram \\ A forditási módok százalékos megoszlása \\ $n=397$}

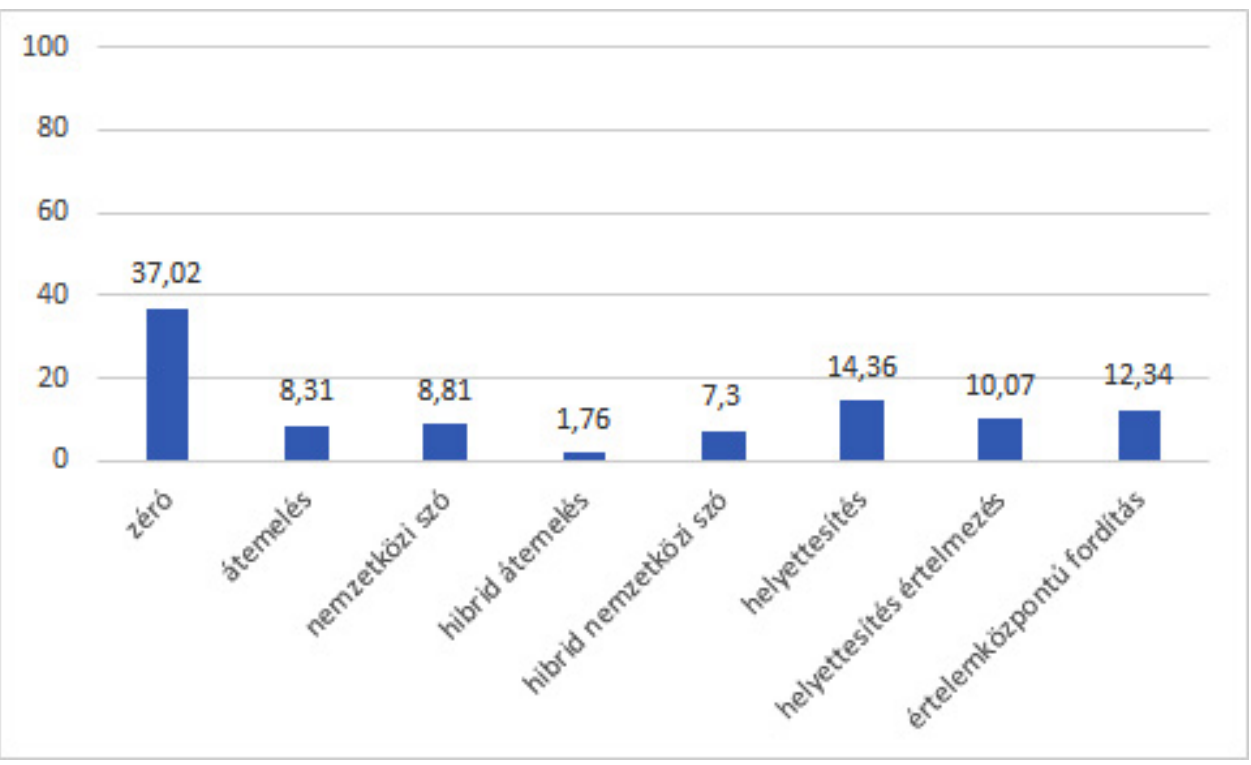

Az 1. diagramból megállapítható, hogy a teljes mintában a zéró fordítás képviseli a legmagasabb arányt 37,02 százalékkal, az átemelés 8,31, a hibrid átemelés pedig 1,76 százalékban szerepel. Az arányokat összegezve, 47,09 százalékot kapunk. A teljes nyelvi mintát tekintve ez azt jelenti, hogy a terminusok közel felében a glosszáriumok vagy nem adnak célnyelvi terminust (zéró fordítás), vagy a célnyelvi terminus részben vagy egészben átemeléssel jön létre. A zéró fordítás és az átemelés célnyelvre gyakorolt hatása hasonló: a nyelvhasználó jó eséllyel a forrásnyelvi terminust használhatja a célnyelvi diskurzusban, ezzel utat nyitva a kódkeverésnek.

A nemzetközi szóval vagy nemzetközi szót tartalmazó hibrid alakulattal történő fordítás 8,81 és 7,30 százalékban fordul elö. Ez a fordítási mód az interferencia szempontjából sajátos átmenetet képez a zéró fordítás/átemelés és a célnyelvi elemekből építkező helyettesítés között. Ahogy a fentiekben már említettem, a nemzetközi szavak kisebb része csak szűk szakmai körökben használt, ezért kevésbé transzparens a laikus nyelvhasználó számára. A köznyelvben is használt nemzetközi szavak nagyobb része kommunikációs zavart akkor okozhat, ha fogalmi tartalmuk a tárgykörben megváltozik, vagyis a már ismert tartalom helyett a nyelvhasználó új tartalommal szembesül.

A célnyelvi helyettesítés, vagyis a tükörfordítás és a jelentéskölcsönzés a minta 14,36 százalékában figyelhető meg. Mivel az így keletkezett terminusok célnyelvi elemekböl épülnek fel, jól illeszkednek a célnyelvi rendszerbe, könnyen képezhetők és ragozhatók, valamint nem okoznak idegenszerüséget a diskurzusban. 
A nemzetközi szavakhoz hasonlóan, értelemzésüket és használatukat a köznyelvitől eltérő fogalmi tartalom nehezíti meg. A mintában található olyan tükörfordítás, amely fogalmi tartalma más tárgykörböl már jól ismert az átlagos felhasználó számára is, léteznek azonban olyan terminusok, amelyek fogalmi tartalma részben vagy egészben megváltozik a tárgykörben. Az értelmezési problémák abból adódhatnak, hogy a laikus nyelvhasználó nincs tudatában a jelentésváltozásnak.

A helyettesítés értelmezéssel, amely 10,07 százalékban fordul elö, átmenetet képez a helyettesítés és az értelemközpontú fordítás között. Ez utóbbi 12,34 százalékban mutatható ki. Az értelemközpontú fordítás rámutat a fogalmi transzparenciára való törekvésre. Ennek a fordítási módnak az előnye, hogy a terminus fogalmi tartalmának bizonyos aspektusai a kontextus alapján világossá válhatnak a laikus nyelvhasználó számára is.

Az értelmezésre való törekvés, bár alacsony arányban, de előfordul a hibrid átemelés és a nemzetközi szót tartalmazó hibrid alakulatok esetében is. A hibrid átemelésben az értelmező fordítás kevéssé segíti a teljes terminus értelmezését. Ilyen például a cost per lead - egy lead megszerzésének költsége terminus (vespuccipartners.com). Az értelmező betoldás ellenére a terminus használata interferenciát okozhat a célnyelvi diskurzusban. Ha azonban a hibrid alakulat egyik eleme széles körben ismert nemzetközi szó, a másik elem értelmezése megvilágíthatja a fogalmi tartalmat is, mint például a Chief Marketing Officer-marketingvezetö (vespuccipartners.com) terminus esetében. A marketing a köznyelvben is gyakran használt, míg a chief és az officer értelmezése (vezetö) transzparenssé teszi a fogalmat.

A 2. diagram a 7.1. pontban ismertetett interferenciális, intranszparens és nyelvileg transzparens terminusok arányát mutatja be a teljes mintában terminusismétlődések nélkül. Ha a nyelvhasználó mind a nyolc glosszáriumban keres, akkor a diagramon látható arányban találja a rendelkezésre álló terminusok kategóriáit.

\section{2. diagram}

Az interferenciális, intranszparens és nyelvileg transzparens terminusok százalékos megoszlása

$$
n=238
$$

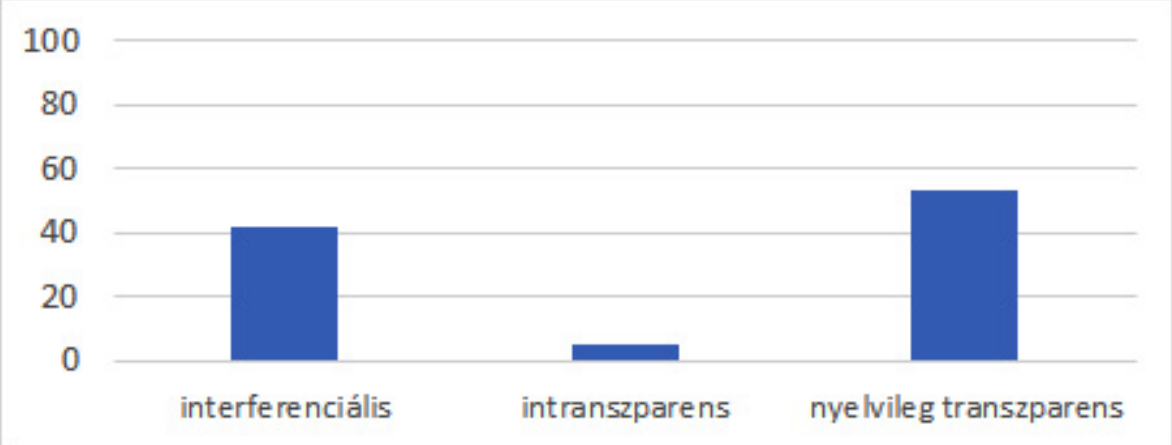


Az interferenciális terminusok viszonylag magas arányban, 42,02 százalékban fordulnak elö. Ezek olyan terminusok, amelyek zéró fordítással, átemeléssel vagy hibrid átemeléssel jönnek létre. Az interferenciális terminusok aránya felhívja a figyelmet a vizsgált glosszáriumokban fennálló célnyelvi terminushiányra, vagyis azokra az esetekre, amikor egyetlen terminológiai forrásban sem található célnyelvi elemekből vagy transzparens nemzetközi szavakból építkező terminus. Ez azt jelenti, hogy a glosszáriumokból tájékozódó nyelvhasználó jó eséllyel olyan terminust talál, amelynek célnyelvi használata kódváltást eredményez.

Az intranszparens terminusok aránya csupán 4,62 százalék a teljes mintában. Ezek nemzetközi szavak és hibrid nemzetközi szavak használatával jönnek létre, átmenetet képezve az interferenciális és nyelvileg transzparens terminusok között. Feltételezhető, hogy a szük szakmai körökben használt terminusokat az átlagos nyelvhasználó a nyelvi honosítás ellenére idegenszerünek érzékeli, esetleg már a szóalak felismerése is problémát jelent. Az interferenciális és intranszparens terminusok arányának összege 46,64 százalékot tesz ki. Ebből arra következtethetünk, hogy a glosszáriumok által ajánlott startup terminusok használata jelentős mértékben hozzájárulhat a célnyelvi diskurzus idegenszerüségéhez és intranszparenciájához a szakember és a laikus közötti kommunikációban.

A nyelvileg transzparens terminusok aránya 53,36 százalék. Ez arra utal, hogy amennyiben a nyelvhasználó mind a nyolc glosszáriumot használja, akkor az esetek valamivel több mint felében talál célnyelvi elemekből vagy transzparens nemzetközi szavakból építkező terminusokat. Ezek a fogalmi tartalom definiálásával alkalmasak lehetnek a szakember és a laikus közötti szakmai kommunikációra anélkül, hogy használatuk kódváltás vagy jelentős mértékü idegenszerüség érzetét keltené.

A vizsgálat eredményei tehát közelítenek a hipotézisben feltételezett értékhez, mely szerint az angol-magyar online startup glosszáriumok szerkesztői közel fele arányban átveszik a forrásnyelvi terminusokat, vagy pedig csak a definíciót adják meg célnyelvi ekvivalens nélkül. (1. 1. diagram: zéró fordítás + átemelés + hibrid átemelés $=47,09 \%$ ). A zéró fordítások, az átemelések és a kevésbé elterjedt nemzetközi szavak használata interferenciális és intranszparens terminusokhoz vezetnek (1. 2. diagram: 46,64\%). Ez terminológiai hiányt vagy jelentős mértékü idegenszerüséget eredményez a célnyelvi rendszerben, teret adva a szakmai szövegekben tapasztalható kódkeverésnek. Az eredmények egybecsengenek az online marketing tárgykörében végzett vizsgálatom eredményeivel (Polcz 2017a; Polcz 2017b.).

Joggal merül fel a kérdés, hogy a célnyelvi terminushiány csak a vizsgált glosszáriumokra vagy a célnyelv egészére is jellemző. A kérdés megválaszolására a vizsgálatot kiterjesztettem egyéb nem glosszárium jellegü internetes forrásokra, mint például startupokkal foglalkozó folyóiratok, szakmai oldalak, vállalati joggal foglalkozó honlapok, terminológiai és fordítói fórumok, párhuzamos szövegek stb., természetesen a teljesség igénye nélkül. Ez rávilágít arra, hogy mit találhat a nyelvhasználó, ha hajlandó elmélyült kutatómunkát végezni a rendelkezésre álló források széles spektrumában. A vizsgálat eredménye a 3. diagramon látható. 


\section{3. diagram \\ Széles spektrumú vizsgálat \\ $n=238$}

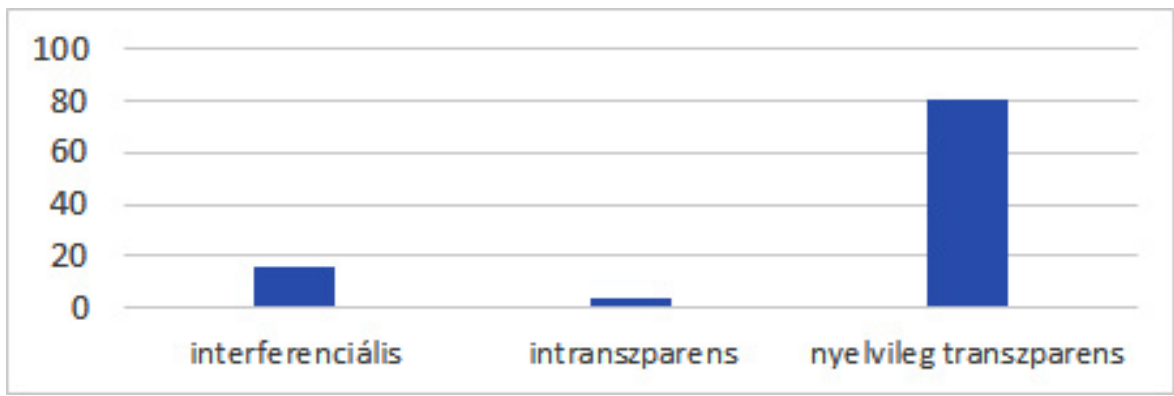

Az adatokból megállapítható, hogy az interferenciális terminusok aránya jóval alacsonyabb, csupán 15,55 százalék, de az intranszparens terminusoké is némileg csökken, 3,78 százalékra. Ezzel összhangban a nyelvileg transzparens terminusok aránya jelentősen magasabb, 80,67 százalék. Mindebböl arra következtethetünk, ha a glosszáriumok szerkesztöi sok esetben nem is tartják fontosnak a célnyelvi elemekből építkező terminusalkotást, a szakma és a laikus nyelvhasználók között közvetítő szakemberek, mint például szakírók, jogászok, fordítók stb. többnyire létrehozzák a nyelvileg transzparens terminusokat, hogy ezzel a nyelvhasználók szélesebb köre számára kódváltás nélkül is lehetővé tegyék a kommunikációt. További kutatást tárgyát képezheti az, hogy az így létrejött terminusok hogyan felelnek meg a terminusalkotási irányelveknek (1. ISO 704: 2009) és a nyelvhasználók kommunikációs igényeinek. Ahogy a fentiekben látható, a nyelvhasználók számára a kihívást az jelenti, hogy a transzparens célnyelvi terminusok felkutatásához számos forrást felölelő kutatómunkára van szükség. Hasonló kutatómunka elvégzésére feltehetően a nyelvhasználók nagy részének sem hajlandósága, sem szakértelme nincs.

\section{Konklúzió}

A kutatás feltérképezte a különböző fordítási módokat a startup vállalkozások terminológiájában, rávilágítva az interferenciális, intranszparens és nyelvileg transzparens terminusok arányára a vizsgált forrásokban és a szélesebb spektrumban is. A kutatási kérdésekre adott válaszokat a következőképpen összegezhetjük. A terminusok közel felében a glosszáriumok vagy nem adnak célnyelvi terminust (zéró fordítás), vagy átveszik a forrásnyelvi terminust. Ennek következtében interferenciális és intranszparens terminusok jönnek létre, amelyek kódkeverést vagy idegenszerüséget okozhatnak a célnyelvi diskurzusban. A széles spektrumú vizsgálat adatai azonban azt mutatják, hogy a nyelv nagyrészben „kitermeli” a nyelvileg transzparens terminusokat, lehetővé téve ezzel a szakma és a laikus nyelvhasználó közötti kommunikációt. 
A kölcsönzött forrásnyelvi elemek gyakran beépülnek a köznyelvbe is, mint például a startup, a marketing vagy a brand terminusok. A célnyelvbe már integrálódott terminusok esetében megkérdőjeleződik a magyarítás szükségessége. Gondoljunk például az 5. pontban említett startup terminusra, amelynek a Bankszövetség pályázatában a díjnyertes magyar megfelelöje az innovállalat lett. Az új terminus az innováció és a vállalat elemekből létrejött hibrid alakulat, amelynek első eleme az újkori latin eredetủ innovatio szóból eredeztethetö (Tóthfalusi 2008: 435). Napjainkban a startup terminus olyannyira elterjedt több nyelvben is, hogy joggal követelheti magának a nemzetközi szó státuszát. Kérdés, hogy érdemes-e lecserélni az egyik nemzetközi szót a másikra csak azért, mert az innováció szót a magyar nyelv korábban vette át.

A forrásnyelvi terminusok nagyobb részének széles körü célnyelvi elterjedése azonban nem lehetséges. Ezeken a pontokon terminushiány lép fel, ami zavart okozhat a szakember és a laikus közötti kommunikációban. Az interferenciális terminusok nehezen illeszkednek a célnyelvi diskurzusba, gyakran a kódváltás érzetét keltik, ezért általában nem alkalmasak arra, hogy kielégítsék a nem szakmai vagy félszakmai közönség kommunikációs igényeit. A nyelvi szakemberek, szakírók és oktatók nehéz helyzetbe kerülnek, hiszen nem áll rendelkezésre a nyelvi közvetítést és a szövegalkotást lehetővé tévő transzparens célnyelvi terminológia, gondoljunk egy szakkönyv lefordítására, egy szakmai előadásra, a tolmácsolásra, vagy egy ismeretterjesztő cikk megírására a tágabb közönség számára, de a szaknyelvoktatás is számos kérdést vet fel. Óhatatlanul felléphet a kódkeverés lehetősége, ami nehezen értelmezhetővé és idegenszerüvé teszi a célnyelvi szövegeket.

A vizsgálat arra is rámutatott, hogy az interferenciális terminusok jelentős része nyelvileg transzparens formában is előfordul a célnyelvi diskurzusban. Ezek felkutatása azonban jelentős erőfeszítéssel jár, amit a nyelvhasználók szakértelem és idő hiányában nem feltétlenül tesznek meg. Éppen ezért fontos, hogy a szétszórtan előforduló célnyelvi terminusokat a nyelvi és gazdasági szakemberek közös kutatómunkával egy platformra rendezzék, egységesítsék, valamint, amennyiben szükséges, megoldásokat keressenek a valós terminushiányra. Ez a terminológiai munka lehet az első lépés egy szakmailag adekvát startup szótár megalkotásához, amely kiszolgálhatná az egyes felhasználói csoportok kommunikációs igényeit: a jogi és gazdasági szakemberekét (jogászok, közgazdászok, vállalkozók, oktatók stb.), a nyelvi szakemberekét (fordítók, terminológusok, tolmácsok, nyelvtanárok) és a laikus nyelvhasználókét.

\section{Köszönetnyilvánítás}

Köszönetemet fejezem ki Dr. Huszár Erikának, a Budapesti Gazdasági Egyetem Külkereskedelmi Kar Nemzetközi Üzleti Szaknyelvek Tanszék adjunktusának, hogy az adatok másodkódolását elvégezte. 


\section{Irodalom}

Atkins, B. T., Rundell, M. 2008. The Oxford Guide to Practical Lexicography. New York: Oxford University Press.

Balázs J. 1983. Az areális nyelvészeti kutatások története, módszerei és főbb eredményei. In: Balázs J. (szerk.) Areális nyelvészeti tanulmányok. Budapest: Tankönyvkiadó. $7-112$.

Bergenholtz, H., Agerbo, H. 2017. Types of Lexicographical Information Needs and their Relevance for Information Science. Journal of Information Science Theory and Practice Vol. 5. No. 3. 17-32. https://doi.org/10.1633/JISTaP.2017.5.3.2

Drascau, M. J. A. 2001. The sociolinguistics of terminology with special reference to lesswidely used and revitalised languages. http://citeseerx.ist.psu.edu/viewdoc/download ?doi=10.1.1.569.924\&rep=rep1\&type=pdf (Letöltve: 2020. április 1.)

Encyclopedia Britannica. https://www.britannica.com/technology/stealth (Letöltve: 2020. 03. 26.)

Falk N. 2009. Etimológiák. 10000 magyar szó eredete. Budapest: Tinta.

Fischer M. 2012. Elméleti és módszertani adalék a terminológia oktatásához. Forditástudomány 14. évf. 2. szám 5-29.

Fóris Á., Bérces E. 2006. A wellness terminológiája. Magyar Nyelvőr 130. évf. 4. szám 399-413.

Fuertes-Olivera, P. A., Tarp, S. 2014. Theory and Practice of Specialised Online Dictionaries. Lexicography versus Terminography. Berlin/Boston: de Gruyter. https://doi. org/10.1515/9783110349023

Harvey, M. 2000. A Beginner's Course in Legal Translation: the Case of Culture-bound terms. http:/www.tradulex.com/Actes2000/harvey.pdf (Letöltve: 2015. április 22.)

Haugen, E. 1950. The analysis of linguistic borrowing. Language Vol. 26. No. 1. 210-231. https://doi.org/10.2307/410058

Hendrickson, R. 2004. The Facts on File Encyclopedia of Word and Phrase Origins. New York: Checkmark Books.

ISO 704:2009(E). Terminology work - Principles and methods. ISO

Keresztes Cs. 2003. Az angol nyelv hatása a magyar szakmai nyelvre. In: Tóth Sz. (szerk.) Nyelvek és kultúrák találkozása. Szeged: Szegedi Tudományegyetem Juhász Gyula Tanárképző Főiskolai Kara. 172-176.

Keresztes Cs. 2007. Nyelvi kontaktushatások vizsgálata szakszövegek fordításakor. In: Silye M. (szerk.) Porta Lingua 2007. Szaknyelvoktatásunk - határokon átívelö híd. Budapest: SZOKOE. 295-301.

Kis Á. 1993. A számítástechnikai szaknyelv újratermelödő hibái. Magyar Nyelvőr 117. évf. 4. szám. 564-567.

Kontra M. 1981. A nyelvek közötti kölcsönzés néhány kérdéséről különös tekintettel „elangolosodó” orvosi nyelvünkre. Budapest: Akadémiai Kiadó.

Lanstyák I. 2006. Nyelvböl nyelvbe. Tanulmányok a szókölcsönzésröl, kódváltásról és forditásról. Pozsony: Kalligram Könyvkiadó.

Katona V. N. 2018. Technológiai jellegü innovációs projektek közösségi finanszirozása. Doktori disszertáció. Budapest: Corvinus Egyetem.

Mátyás J. 2018. Anglicizmusok a marketingkommunikációban és a hétköznapi nyelvhasználatban. In: Besznyák R. (szerk.) Porta Lingua - 2018. Tudásmegosztás, értékköz- 
vetités, digitalizáció - trendek a szaknyelvoktatásban és -kutatásban. Budapest: SZOKOE. 419-429.

Morris, C. W. 1946. Signs, Language and Behavior. Englewood Cliffs, NJ: Prentice Hall. https://doi.org/10.1037/14607-000

Murányiné Z. M. 2010. Angol nyelvi hatás az analitikai kémiai tudományos nyelvhasználatában. In: Silye M. (szerk.) Porta Lingua 2010. Tudományterületek és nyelvhasználat. Budapest: SZOKOE. 181-187.

Newmark, P. 1988. Approaches to translation. Hertfordshire: Prentice Hall.

Online Etimology Dictionary. https://www.etymonline.com/word/stealth (Letöltve: 2020. március 26.)

Országh L. Magay T. 1998. Angol-magyar nagyszótár. Budapest: Akadémiai Kiadó.

Polcz K. 2017a. Angol-magyar megfeleltetések az online marketing terminológiájában szakszótárak és internetes glosszáriumok alapján. In: Bocz Zs., Besznyák R. Porta Lingua 2017. Szaknyelvhasználat: a tudomány és a szakma nyelvének alkalmazása. Budapest: SZOKOE. 137-147.

Polcz K. 2017b. Dominant language influence on the Hungarian terminology of online marketing. US-China Foreign Language Vol. 15. No. 5. 287-296. https://doi. org/10.17265/1539-8080/2017.05.001

Rao, A. 2013. A History of Silicon Valley: The Greatest Creation of Wealth in the History of the Planet. Palo Alto, California: Omniware Group.

Sager, J. C. 1998. Terminology, application. In: Baker, M. (ed.) Routledge Encyclopedia of Translation Studies. London: Routledge. 251-255.

Szabó Z. 2010. Marketing szakkifejezések a hazai szakirodalomban és fordítási kérdéseik speciális termékkör esetén. In: Dróth J. (szerk.) Szaknyelv és szakfordítás 2009-2010. Gödöllő: Szent István Egyetem. 28-33.

Szalai B. 2017. Most már tényleg megszünnek a startupok Magyarországon. Index https:// index.hu/gazdasag/2017/03/29/most_mar_tenyleg_megszunnek_a_startupok_magyar orszagon/\# (Letöltve: 2020. március 26.)

Tóthfalusi I. 2008. Idegenszó-tár. Idegen szavak értelmezö és etimológiai szótára. Budapest: Tinta.

Vargáné Kiss K. 2007. Az angol nyelv szerepe a pénzintézeti nyelvhasználatban. In: Silye, M. (szerk.) Porta Lingua 2007 Szaknyelvoktatásunk - határokon átívelö híd. Budapest: SZOKOE. 337-344.

Vargáné Kiss K. 2016. A pénzügyi terminológia fordításának néhány aspektusa. In: Besznyák, R. (szerk.) Porta Lingua - 2016. A szaknyelv rétegzódése a szakmában, az oktatásban és a kutatásban. Budapest: SZOKOE. 179-191.

Vinay, J. P., Dalbernet, J. 1995. Comparative stylistics of French and English: A methodology for translation. Amsterdam: John Benjamins. https://doi.org/10.1075/btl.11

Violino, B. 2019. What is SaaS? Software as a service defined. Infoworld https://www. infoworld.com/article/3226386/what-is-saas-software-as-a-service-defined.html (Letöltve: 2020. március 26.)

Wardhaugh, R. 2010. An introduction to sociolinguistics. Chichester: Wiley-Blackwell. 


\section{Források}

Aha brainstore 2.0: http://ahabrain.store/2019/04/01/startup-szotar-az-alapoktol$\%$ f0\% $\%$ f\% $\% 3 \% 96 /$ (utoljára letöltve 2020. március. 23.)

Budapesti Müszaki és Gazdaságtudományi Egyetem Szakkollégiuma:

https://mszk-bme.hu/a-harombetus-startupper/ (utoljára letöltve: 2020. március 23.)

MVM Edison: https://mvmedison.hu/startup-akademia (utoljára letöltve 2020. március 23.)

Speak Nyelviskola:

https://www.speaknyelviskola.hu/a-10-legfontosabb-startupos-angol-kifejezes/ (utoljára letöltve: 2020. március 23.)

Startup mentorálási kézikönyv: https://start2act.eu/assets/content/D5.3_Handbook\%20 for $\% 20$ startup $\% 20$ energy $\% 20$ mentoring $\% 20$ activities_HU.pdf (utoljára letöltve 2020. március 23.)

StartUpdate: http://startupdate.hu/startup-szotar/ (utoljára letöltve: 2020. március 23.)

Startup Marketing Akadémia: http://startup-marketing-akademia.hu/nagy-startup-marketing-szotar/ (a megjelenés időpontjában a tárolt változat nem érhető el) http:// webcache.googleusercontent.com/search?q=cache:xy_TZvoWAeIJ:startup-marketingakademia.hu/nagy-startup-marketing-szotar/ $\& \mathrm{~cd}=1 \& \mathrm{hl}=$ hu\&ct=clnk\&gl=hu\&client =firefox-b-d (utoljára letöltve: 2020. március 23.)

Vespucci Partners: https://vespuccipartners.com/bejegyzes/startup-szotar-marketing-kifejezesek,

https://vespuccipartners.com/bejegyzes/startup-szotar-programozoi-es-fejlesztoi-kifejezesek, https://vespuccipartners.com/bejegyzes/startup-szotar-uzleti-kifejezesek (utoljára letöltve 2020. március. 23.) 